\title{
Conserving migratory waterbirds and the coastal zone: the future of South-east Asia's intertidal wetlands
}

\author{
Ding Li Yong, Jing Ying Kee, Pyae Phyo Aung, AnujJain, Chin-Aik Yeap \\ Nyat Jun Au, Ayumat Jearmattanakanok, Kim Keang Lim, Yat-Tung Yu \\ Vivian W. K. Fu, Paul Insua-Cao, Yusuke Sawa, Mike Crosby \\ Simba Chan and Nicola J. CROCKFord
}

\begin{abstract}
South-east Asia's diverse coastal wetlands, which span natural mudflats and mangroves to man-made salt pans, offer critical habitat for many migratory waterbird species in the East Asian-Australasian Flyway. Species dependent on these wetlands include nearly the entire population of the Critically Endangered spoon-billed sandpiper Calidris pygmaea and the Endangered spotted greenshank Tringa guttifer, and significant populations of several other globally threatened and declining species. Presently, more than 50 coastal Important Bird and Biodiversity Areas (IBAs) in the region ( $7.4 \%$ of all South-east Asian IBAs) support at least one threatened migratory species. However, recent studies continue to reveal major knowledge gaps on the distribution of migratory waterbirds and important wetland sites along South-east Asia's vast coastline, including undiscovered and potential IBAs. Alongside this, there are critical gaps in the representation of coastal
\end{abstract}

Ding LI Yong (Corresponding author, (1) orcid.org/0000-0003-3115-6916) and ANUJ JAIN (10) orcid.org/0000-0001-9837-4163 BirdLife International (Asia), 354 Tanglin Road, \#01-16/17, Tanglin International Centre, Singapore E-mail dingli.yong@birdlife.org

JING YING Kee National University of Singapore, Singapore

Pyae Phyo Aung (당 orcid.org/0000-0001-9249-4041) Nature Conservation Society Myanmar, Yangon, Myanmar

Chin-Aik YeAP and Nyat Jun Au Malaysian Nature Society, Kuala Lumpur, Malaysia

Vivian W. K. Fu East Asian-Australasian Flyway Partnership, Incheon, Republic of Korea

Ayuwat Jearwattanakanok Bird Conservation Society of Thailand, Bangkok, Thailand

Kim KeAng Lim Nature Society (Singapore), Singapore

Yat-Tung Yu (@ orcid.org/0000-0002-7327-0461) Hong Kong Bird Watching Society, Hong Kong SAR, China

YUSUKE SAWA Yamashina Institute for Ornithology, Chiba, Japan

Simba Chan BirdLife International, Tokyo, Japan

Paul Insua-Cao and Nicola J. Crockford Royal Society for the Protection of Birds, Sandy, UK

Mike Crosby BirdLife International, Cambridge, UK

Received 9 July 2020. Revision requested 25 September 2020.

Accepted 11 December 2020. First published online 21 October 2021. wetlands across the protected area networks of many countries in this region (e.g. Viet Nam, Indonesia, Malaysia), hindering effective conservation. Although a better understanding of the value of coastal wetlands to people and their importance to migratory species is necessary, governments and other stakeholders need to do more to strengthen the conservation of these ecosystems by improving protected area coverage, habitat restoration, and coastal governance and management. This must be underpinned by the judicious use of evidence-based approaches, including satellite-tracking of migratory birds, ecological research and ground surveys.

Keywords Coastal governance, coastal wetlands, East Asian-Australasian Flyway, Important Bird and Biodiversity Area, migratory species, mudflat, protected areas, Ramsar Convention

\section{Introduction}

outh-east Asia's coastal wetlands are among the region's $\checkmark$ most overlooked ecosystems for biodiversity conservation in spite of their diverse roles in provisioning ecosystem services such as carbon sequestration (Suratman, 2008; Donato et al., 2011), disaster risk mitigation (de Groot et al., 2012; Kuenzer \& Renaud, 2012) and livelihoods to human communities through supporting key fisheries (Brander et al., 2012; Murata et al., 2016). These dynamic ecosystems form global centres of diversity for taxa such as mangroves, seagrasses and horseshoe crabs (Chou, 1994; Ooi et al., 2011; Obst et al., 2012, Richards \& Friess, 2016), and provide critical habitats for migratory waterbird species (Zöckler et al., 2018a,b; Chan et al., 2019) and nesting sea turtles (MacKinnon et al., 2012). Amidst a broad focus on conservation of tropical forests in South-east Asia (e.g. Sodhi et al., 2010), less species-rich ecosystems in this region, such as coastal wetlands, have been less studied (e.g. Friess et al., 2012) and are often underrepresented in conservation discourse (Coleman et al., 2019). 
With a better understanding of the importance of coastal wetlands to migratory waterbirds in the East AsianAustralasian Flyway (Yang et al., 2011; Murray et al., 2014; Duan et al., 2020) and the ecosystem services they provide, there has been renewed urgency to strengthen the conservation of networks of coastal wetland sites (Bamford et al., 2008). Recent efforts by China and South Korea to restore coastal wetlands, limit coastal reclamation (Kim, 2018; Zhou, 2018) and successfully promote coastal wetland sites for World Heritage Site listing (UNESCO WHC, 2019), and by Myanmar to expand its Ramsar Sites (Myat Moe Aung, 2020), offer renewed momentum for wetland conservation in the region. However, the loss and conversion of coastal wetlands throughout Asia continues because of the economic pressures on the low-lying coastal zone, ranging from urban, industrial and infrastructure development to rice and oil palm monoculture, and fish farming (Chou, 1994; MacKinnon et al., 2012; Ma et al., 2014; Richards \& Friess, 2016).

Recent analyses of the distribution of coastal wetlands show that the South-east Asian region (e.g. Indonesia, Myanmar, Viet Nam) holds some of the largest areas of mudflats (Murray et al., 2019) and mangroves (Richards \& Friess, 2016) globally. Yet, there are significant knowledge gaps in the state of South-east Asia's wetland ecosystems, and how wetland sites are connected by migratory waterbird populations (e.g. Choi et al., 2016; Chan et al., 2019). This is accentuated by the region's long and poorly surveyed coastlines (e.g. Borneo, Wallacea, Philippines, New Guinea; Chou, 1994). Additionally, many wetlands in South-east Asia, including even protected sites, are being increasingly impacted by encroachment and aquaculture expansion (Eng et al., 1989; Round, 2006; Yasue \& Dearden, 2009), sand mining and other forms of unsustainable coastal development (Hilton \& Manning, 1995; Yeap et al., 2007) before they can be studied. Migratory waterbird populations also under significant hunting pressure in many parts of the Flyway (Turrin \& Watts, 2016), particularly in South-east Asia where there have been well-documented instances of unsustainable offtake (Gallo-Caijiao et al., 2020).

Here, we synthesize recent developments in migratory waterbird conservation in South-east Asia (herein defined to include all Association of South-east Asian Nations states, and Timor-Leste), and discuss knowledge gaps in the conservation of coastal wetlands and migratory waterbirds, with a focus on coastal Important Bird and Biodiversity Areas (IBAs) in this region (BirdLife International, 2004, 2020a; see Table 1 for definitions). We used a definition of coastal wetlands following the wetland classification scheme adopted by the Ramsar Convention Secretariat (2016); in this region coastal wetlands largely consist of intertidal mud and sand flats, estuarine waters, sandy shores and mangroves, and associated supratidal areas such as salt pans and aquaculture ponds. We then review anthropogenic threats faced by these wetlands and argue that a combination of better science and political commitment is needed to secure the future of South-east Asia's valuable coastal wetlands.

\section{Importance of coastal wetlands}

\section{Key sites for migratory waterbirds}

Of 672 IBAs identified within South-east Asia, 181 (26.9\%) hold some form of coastal wetland cover, of which 52 are identified here to support at least one globally threatened migratory waterbird (Fig. 1). Presently, Indonesia holds the largest number and area of IBAs with coastal wetlands (86 sites totalling c. $84,533 \mathrm{~km}^{2}$ ), followed by Myanmar (three sites totalling c. $12,646 \mathrm{~km}^{2}$ ) and Malaysia (15 sites totalling c. $4,316 \mathrm{~km}^{2} ;$ Fig. 1). At least seven key coastal areas in the region have been identified that are crucial for migratory shorebirds, all comprising IBAs or clusters of IBAs (MacKinnon et al., 2012): the Inner Gulf of Thailand, the Gulf of Mottama (Myanmar), the Mekong and Red River deltas (Viet Nam), the west coast of Peninsular Malaysia, the Sarawak coastline (Malaysia), and the southeast coast of Sumatra (Indonesia).

The Malacca Strait coastlines of Peninsular Malaysia and Sumatra collectively hold the most extensive areas of intertidal flats, mangroves and associated wetlands in South-east Asia for significant congregations of migratory waterbirds (Crossland et al., 2006; Li et al., 2006; Iqbal et al., 2010), with large areas of coastal wetlands on both sides of the straits recognized as IBAs. In the 1990s, Verheugt et al. (1992) estimated 500,000 migratory shorebirds on the coast of South Sumatra province alone, which extrapolated to $>_{1}$ million shorebirds staging or wintering along the Sumatran coast. Surveys post-2010 continue to demonstrate the importance of Sumatra's east coast for wintering shorebirds, with many species meeting the $1 \%$ threshold of their flyway population, a key criterion for Ramsar site designation (Iqbal et al., 2010). New sites continue to be discovered (Putra et al., 2017; Putra et al., 2019), reflecting the substantial gaps in knowledge.

Further north, the Inner Gulf of Thailand is one of South-east Asia's best-surveyed coastlines for migratory waterbirds (e.g. Round, 2006). Its representation of coastal wetland types includes artificial supratidal wetlands such as salt pans, and intertidal flats and mangroves (Round, 2006; Yasue \& Dearden, 2009; Yu et al., 2020), and supports globally significant congregations of shorebirds, with an estimated 30,000-40,000 individuals in midwinter (Sripanomyom et al., 2011). In Myanmar, surveys of the spoon-billed sandpiper Calidris pygmaea on the vast intertidal wetlands along the poorly surveyed Gulf of Mottama have revealed these coastlines to be internationally important for migratory waterbirds, supporting an estimated total of 150,000 individuals of 80 species (Zöckler et al., 2014; Aung et al., 2020). 
TABLE 1 Definitions of key terms.

\begin{tabular}{|c|c|c|}
\hline Term & Definition & Source \\
\hline $\begin{array}{l}\text { Important Bird \& } \\
\text { Biodiversity Area }\end{array}$ & $\begin{array}{l}\text { Sites identified to be significant for the conservation of bird species \& other } \\
\text { biodiversity, based on internationally agreed, standardized data-driven criteria } \\
\text { (e.g. globally threatened species, restricted range species, congregations) \& a } \\
\text { consultative process. }\end{array}$ & $\begin{array}{l}\text { BirdLife International } \\
\text { (2004) }\end{array}$ \\
\hline Ramsar site & $\begin{array}{l}\text { Key wetlands recognized for their international importance, protected by } \\
\text { governments under their obligations to the Convention on Wetlands of } \\
\text { International Importance, also known as the Ramsar Convention. }\end{array}$ & $\begin{array}{l}\text { Ramsar Convention } \\
\text { Secretariat (2016) }\end{array}$ \\
\hline Flyway Site Network & $\begin{array}{l}\text { Key wetland sites identified for the conservation of migratory waterbirds, } \\
\text { based on standardized criteria under the East Asian-Australasian Flyway } \\
\text { Partnership. All sites in the Network are designated by national government } \\
\text { partners to the Partnership. Nearly } 150 \text { sites have been designated so far. }\end{array}$ & EAAFP (2018) \\
\hline $\begin{array}{l}\text { East Asian- } \\
\text { Australasian Flyway } \\
\text { Partnership }\end{array}$ & $\begin{array}{l}\text { A network of partners consisting of governments, intergovernmental organi- } \\
\text { zations, international organizations, NGOs \& the private sector, aiming to } \\
\text { conserve migratory waterbirds \& wetland habitats in the Partnership; secre- } \\
\text { tariat is based in Incheon, South Korea. }\end{array}$ & EAAFP (2018) \\
\hline $1 \%$ criterion/threshold & $\begin{array}{l}\text { Used in the identification of globally important wetland sites for migratory } \\
\text { waterbird conservation. A wetland is considered internationally important if it } \\
\text { supports at least } 1 \% \text { of the individuals of a population of a waterbird species or } \\
\text { subspecies. }\end{array}$ & $\begin{array}{l}\text { BirdLife International } \\
\text { (2004); Ramsar } \\
\text { Convention Secretariat } \\
\text { (2016); EAAFP (2018) }\end{array}$ \\
\hline
\end{tabular}

\section{Threatened waterbirds}

Field surveys, citizen science monitoring and satellite tracking data collectively confirm South-east Asia's coastal wetlands to be important for at least 12 globally threatened waterbird species, of which seven are migratory (Table 2) and five resident (e.g. the Philippine duck Anas luzonica and milky stork Mycteria cinerea). A further 13 species are Near Threatened. Two of the most imperilled species on the East Asian-Australasian Flyway, the spoon-billed sandpiper (Zöckler et al., 2014; Aung et al., 2020) and spotted greenshank Tringa guttifer (Sripanomyom et al., 2011), have global wintering strongholds concentrated in Southeast Asia (Zöckler et al., 2018a; Yu et al., 2020). The region supports nearly the entire Chinese egret Egretta eulophotes population in winter (BirdLife International, 202ob), and globally significant wintering congregations at various South-east Asian sites ( $>1 \%$ of flyway populations; Ramsar Convention Secretariat, 2016) of the black-faced spoonbill Platalea minor (Xuan Thuy, Viet Nam), great knot Calidris tenuirostris (many sites) and far eastern curlew Numenius madagascariensis (Bako-Buntal Bay, Sarawak) (Li et al., 2006; Bakewell et al., 2017; BirdLife International, 2020a).

Although there is now substantial knowledge of the status and distributions of many waterbirds in this region, there remain large gaps in our understanding of their distribution, ecology and population concentrations in South-east Asia's coastal wetland sites. For example, despite the high survey effort for the spoon-billed sandpiper and spotted greenshank, previously unknown wintering sites continue to be discovered for both species (Putra et al., 2019; Nguyen et al., 202O; Yu et al., 2020). Using satellite trackers on migrating great knot, Chan et al. (2019) found that $63 \%$ of stopover sites used by the species were previously unknown, with the majority of such sites in South-east Asia, and particularly in Borneo, the Philippines, Wallacea and New Guinea. Much of the New Guinea coastline has not been surveyed for migratory shorebirds in recent years despite having vast, little-disturbed areas of estuarine wetlands, and further fieldwork is expected to uncover new sites for species such as the far eastern curlew (Bishop, 2006). Recent studies (Yasue \& Dearden, 2009; Sripanomyom et al., 2011; Jackson et al., 2020), have demonstrated the importance of supratidal artificial wetlands (e.g. salt pans, ash ponds) in South-east Asia to threatened shorebirds such as the spotted greenshank and far eastern curlew, complementing the role of natural tidal flats.

\section{Key challenges for conserving coastal wetlands}

Many important wetlands remain largely unprotected and at the mercy of the development agendas of various countries. Land-use change as a result of aquaculture, energy, infrastructure and residential development, sand mining and land reclamation are the leading drivers of wetland conversion and loss in South-east Asia (Round, 2006; Lim \& Posa, 2014; Lai et al., 2015; Jensen, 2018). Aquaculture intensification for fish and prawn farming across coastal South-east Asia, and the expansion of wet paddy cultivation and mega coastal development projects for ports and residential areas have contributed to the widespread reclamation and degradation of mangroves, salt marshes, seagrass beds and mudflats (de Graaf \& Xuan, 1998; Richards \& Friess, 2016; 


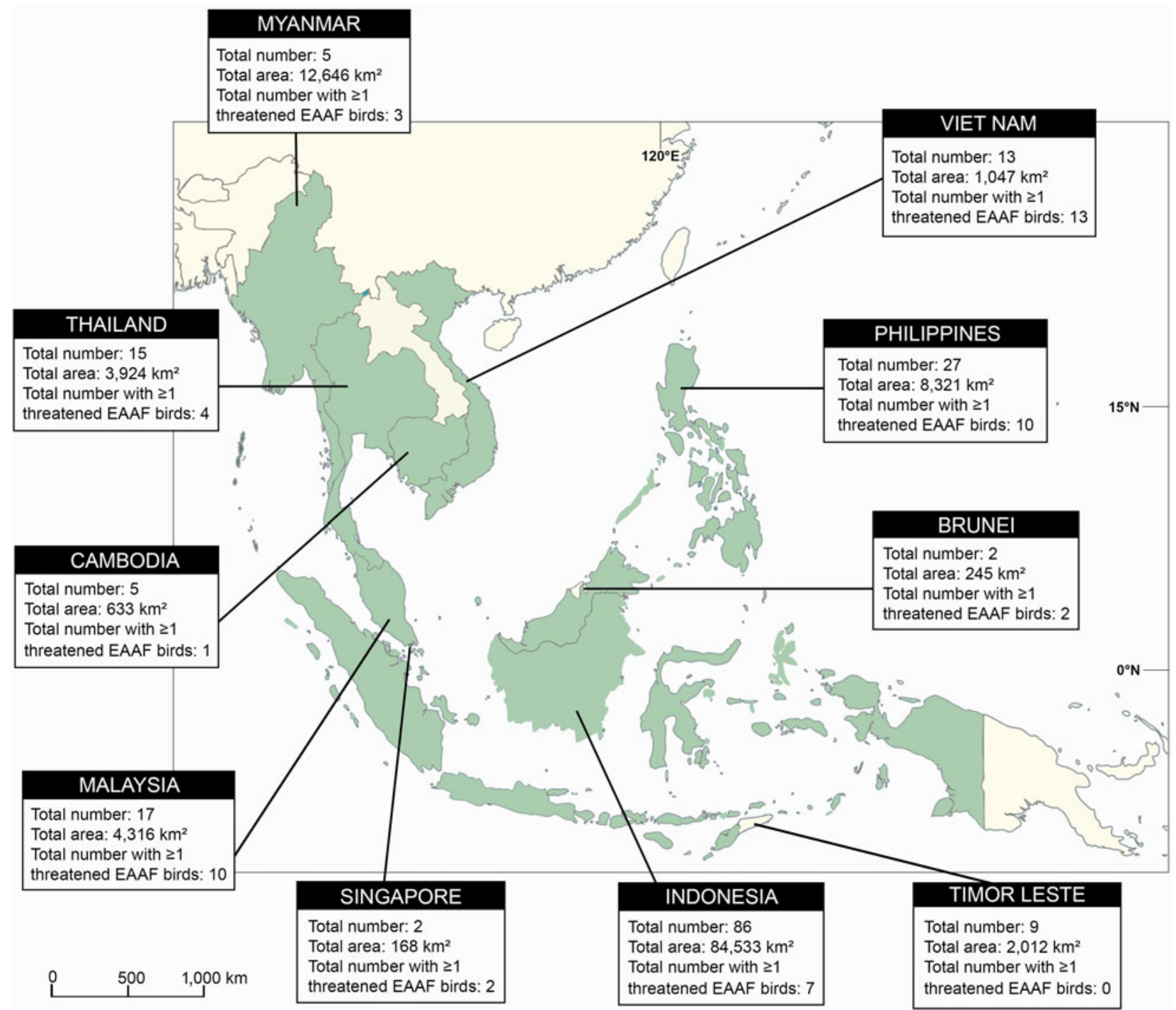

FIG. 1 Total number and area of coastal Important Bird and Biodiversity Areas (IBAs) and total number of coastal IBAs with $\geq 1$ threatened bird species in South-east Asia that overlap with coastal wetlands and support threatened migratory species.

Rahman, 2017; Jensen, 2018), leading to a loss of habitat for migratory waterbird species (Pedersen \& Nielsen, 1998; Buckton \& Safford, 2004; Yasue \& Dearden, 2009). Over time, coastal erosion, exacerbated by anthropogenic alteration of the sediment regimes of rivers and sea level rise poses a threat to coastal wetlands, especially in the Mekong Delta and the Gulf of Thailand (Duriyapong \& Nakhapakorn, 2011; Kuenzer \& Renaud, 2012; Marchesiello et al., 2019).

Presently, at least seven coastal IBAs in South-east Asia are already considered to be IBAs in Danger (BirdLife International, 2020a). Coastal wetlands in Singapore have suffered the greatest relative decline of any South-east Asian country as a result of urban expansion and coastal reclamation (Lai et al., 2015); from 1922 to 1993 intertidal sand/mudflat extent declined by $>75 \%$, to $8 \mathrm{~km}^{2}$ (Hilton \& Manning, 1995). In addition to extensive habitat contraction in this region, migratory waterbird populations are probably also affected by unsustainable hunting pressure (Turrin \& Watts, 2016; Gallo-Caijiao et al., 2020).

Although wetland restoration has slowed the decline of mangroves in some countries in the region (e.g. Philippines, Thailand; Erftemeijer \& Lewis, 1999; Friess et al., 2020), the longer-term outlook for the conservation of South-east Asia's coastal wetlands remains poor. Across the region, a pervasive problem is poorly planned mangrove planting on natural mudflats under the pretext of habitat rehabilitation (Erftemeijer \& Lewis, 1999), which in some instances has further contributed to the loss of habitat for migratory waterbirds (Jensen, 2018).

Many coastal wetland sites of conservation significance in this region receive little or no legal protection and are unrepresented in the national protected area estate 
TABLE 2 Globally threatened migratory waterbirds dependant on coastal wetlands in South-east Asia, and countries with significant staging and/or wintering populations.

\begin{tabular}{|c|c|c|c|}
\hline Species & $\begin{array}{l}\text { Red List } \\
\text { status }^{1}\end{array}$ & Country $^{2}$ & Source \\
\hline \multicolumn{4}{|l|}{ Herons, egrets and spoonbills } \\
\hline Chinese egret Egretta eulophotes & $\mathrm{VU}$ & $\begin{array}{l}\text { Philippines, Malaysia, Thailand, } \\
\text { Viet Nam, Cambodia }\end{array}$ & BirdLife International (2020b) \\
\hline $\begin{array}{l}\text { Black-faced spoonbill Platalea minor } \\
\text { Gulls and terns }\end{array}$ & $\mathrm{EN}$ & Viet Nam (N), Philippines & Ueta et al. (2002) \\
\hline $\begin{array}{l}\text { Saunders's gull Saundersilarus saundersi } \\
\text { Shorebirds }\end{array}$ & VU & Viet $\operatorname{Nam}(\mathrm{N})$ & Pedersen \& Nielsen (1998) \\
\hline Spotted greenshank Tringa guttifer & EN & $\begin{array}{l}\text { Thailand, Malaysia (W), Indonesia (W), } \\
\text { Myanmar (S) }\end{array}$ & Zöckler et al. (2018a) \\
\hline $\begin{array}{l}\text { Far eastern curlew Numenius } \\
\quad \text { madagascariensis }\end{array}$ & $\mathrm{EN}$ & Malaysia (E), Philippines (C), Indonesia & Bakewell et al. (2017) \\
\hline Great knot Calidris tenuirostris & EN & $\begin{array}{l}\text { Malaysia, Thailand, Indonesia, Viet Nam (S), } \\
\text { Myanmar }\end{array}$ & $\begin{array}{l}\text { Putra et al. (2017); } \\
\text { Bakewell et al. (2017) }\end{array}$ \\
\hline $\begin{array}{l}\text { Spoon-billed sandpiper Calidris } \\
\text { pygmaea }\end{array}$ & CR & Myanmar (C, S), Thailand (C), Viet Nam (S) & $\begin{array}{l}\text { Buckton \& Safford (2004); } \\
\text { Zöckler et al. (2016); } \\
\text { Aung et al. (2020) }\end{array}$ \\
\hline
\end{tabular}

${ }^{1} \mathrm{VU}$, Vulnerable; EN, Endangered; CR, Critically Endangered (IUCN, 2021).

${ }^{2} \mathrm{~N}$, north; S, south; E, east; W, west; C, central.

(MacKinnon et al., 2012; Nguyen et al., 2020). In the Inner Gulf of Thailand, few coastal sites important to migratory shorebirds have formal protection under Thai legislation or are actively managed (e.g. Round, 2006; Yu et al., 2020). Viet Nam has a well-established network of protected areas but coastal wetlands are poorly represented (Rambaldi et al., 2001), and in the Philippines and Malaysia many of the most important coastal wetlands for migratory shorebirds (e.g. large tracts of Manila Bay, coastline of mainland Penang) lack formal protection (Yeap et al., 2007; Jensen, 2018).

The conservation of coastal wetland ecosystems in South-east Asia is impeded by a number of fundamental institutional challenges. Firstly, throughout the region, conservation prioritization has emphasized species-rich tropical forests, and charismatic terrestrial and endemic megafauna (e.g. Sodhi et al., 2010; Yong et al., 2018), often overlooking coastal wetlands and other ecosystems with a lower profile. Secondly, the management of coastal resources, including intertidal wetlands and mangrove forests, often slips into the ambiguities and gaps in governance between agencies overseeing terrestrial and marine resources (Mackinnon et al., 2012). The low-lying coastal belt across much of South-east Asia is densely populated and human populations continue to grow (e.g. Chou, 1994). This threatens coastal wetlands with intensive development, land reclamation and expansion of aquaculture, whilst remaining $\mathrm{mud} / \mathrm{sand}$ flats and mangrove forests are under pressure from shellfisheries, fisheries and fuelwood harvesting. Any conservation intervention needs to negotiate a complex entanglement of local communities and their livelihood needs, coastal development agendas, and the various hierarchies of government.

\section{Discussion}

The extent and underlying causes of the decline of many migratory waterbird populations in the East Asian-Australasian Flyway are increasingly understood (Murray et al., 2014; Piersma et al., 2016; Studds et al., 2017). The importance of coastal wetlands for carbon storage, disaster risk reduction under climate change scenarios, and ecosystem service provisioning is now relatively well acknowledged and increasingly mainstreamed into major policy frameworks and initiatives (e.g. McLeod et al., 2011; Friess et al., 2020). One persistent challenge, however, is that important gaps remain in knowledge of the distribution and ecology of threatened migratory species in the region. Recent satellite tracking research is only beginning to address this (Chan et al., 2019), and to complement ground-based field surveys (Putra et al., 2019; Nguyen et al., 2020). There remains an urgent need for continued field-based research to determine (1) where the key migratory bird congregations are, (2) species use of the various wetland types, and (3) migratory routes and the migratory connectivity of waterbird populations, which can guide the identification of priority sites such as IBAs and the planning of protected areas.

All countries in South-east Asia are party to the Convention on Biological Diversity, and all but Brunei, Singapore and Timor-Leste to the Ramsar Convention. In 2018 these Conventions called for the establishment of a multi-stakeholder global coastal forum to facilitate coastal wetland conservation (Ramsar Convention Resolution XIII.2O, Convention on Biological Diversity Decision 14/30). All South-east Asian countries except Laos, Brunei and Timor-Leste are also partners in the East Asian- 
Australasian Flyway Partnership. Partner countries can designate Flyway Network Sites that similarly meet the criteria for Ramsar Sites (Ramsar Convention Secretariat, 2016; EAAFP, 2018), and therefore directly drive work to improve the protection and management of priority wetland sites. Several countries have also established frameworks and initiatives at the national level to address the conservation of wetlands and migratory birds (e.g. Myanmar, Thailand, Indonesia).

However, these frameworks on their own are unlikely to conserve South-east Asia's coastal wetlands if there is no sustained commitment from governments and local stakeholders. Fulfilling these commitments would require substantial effort to improve the representation of coastal wetlands in national protected area networks and community conservation areas (Borrini-Feyerabend et al., 2004), to promote integrated coastal zone management, and to better define the remit of various agencies in relation to the management of the coastal zone. In particular, there is a need to implement better zoning of coastlines to plan for sustainable coastal land use and to facilitate managed retreat and coastal restoration under projected climate change scenarios (Hino et al., 2017). In instances where migratory waterbirds are directly benefiting from man-made wetlands (e.g. Inner Gulf of Thailand; Round, 2006; Yasue \& Dearden, 2009; Sripanomyom et al., 2011; Jackson et al., 2020; Nguyen et al., 2020), there is a window of opportunity for authorities to encourage low-intensity, sustainable uses of the coastal zone, such as through artisanal fisheries and salt farms, an approach already promoted under the Ramsar Convention.

To strengthen the conservation of coastal wetlands in the region, there is evidently a critical role for conservation organizations to work more closely with local people, academia and governments to understand the socio-economics of these communities, promote local custodianship of wetland sites and put livelihoods on a more sustainable and equitable footing (e.g. Borrini-Feyerabend et al., 2004), in collaboration with regional frameworks such as the Association of Southeast Asian Nations. Examples exist of successful engagement with local communities on coastal wetland conservation in this region, particularly in Myanmar's Gulf of Mottama, parts of the Gulf of Thailand (e.g. community participation in the establishment and management of a new nature reserve), the Philippines (Denyer et al., 2018; Zöckler et al., 2018b; Jearwattanakanok \& Yong, 2019), and elsewhere in the world, such as the Wadden and Yellow Sea (Boere \& Piersma, 2012; UNESCO WHC, 2019). These offer good lessons and scalable models of engagement, and demonstrate that the challenges faced in South-east Asia are not insurmountable.

Acknowledgements We thank Eduardo Gallo-Caijiao for useful discussions on the hunting of shorebirds in South-east Asia; K. David Bishop, Batrisyia Teepol, David Li, Arne Jensen, Taej Mundkur, Vinayagan Dharmarajah and Christoph Zöckler for discussions on the conservation status of specific shorebird species in South-east Asia; and two anonymous reviewers and the Editor for their constructive feedback. We dedicate this article to our colleague, the late Balu Perumal, a passionate conservationist whose pioneering work on wetland conservation and environmental education in Malaysia and across the region, was tragically cut short by his untimely passing in August 2021.

Author contributions Study design: DLY; data analysis: DLY, A Jain, JYK; writing: DLY, PPA, A Jain, C-AY, NJA, A Jearwattanakanok, KKL, YTY, VWKF, PI-C, SC, MC, NJC, YS.

\section{Conflicts of interest None.}

Ethical standards This research abided by the Oryx guidelines on ethical standards.

\section{References}

Aung, P.P., Moses, S., Clark, N.A., Anderson, G.A., Hilton, G.M., Buchanan, G.M. et al. (2020) Recent changes in the number of spoon-billed sandpipers Calidris pygmaea wintering on the Upper Gulf of Mottama in Myanmar. Oryx, 54, 23-29.

Bakewell, D., Wong, A., Kong, D. \& Au, R. (2017) Waterbird Surveys of the Sarawak Coast (2010-2012). Malaysian Nature Society-Bird Conservation Council (MNS-BCC) and Sarawak Forestry Corporation, Malaysia.

Bamford, M., Watkins, D., Bancroft, W., Tischler, G. \& Wahl, J. (2008) Migratory Shorebirds of the East Asian-Australasian Flyway: Population Estimates and Internationally Important Sites. Wetlands International Oceania, Canberra, Australia.

Birdife International (2004) Important Bird Areas in Asia: Key Sites for Conservation. BirdLife International, Cambridge, UK.

Birdife International (2020a) Data Zone. datazone.birdlife.org/ home [accessed 6 July 2020].

BirdLife International (2020b) Species factsheet: Egretta eulophotes. datazone.birdlife.org/species/factsheet/Chinese-Egret [accessed 6 July 2020].

BISHOP, K.D. (2006) Shorebirds in New Guinea: their status, conservation and distribution. Stilt, 50, 103-134.

Boere, G.C. \& Piersma, T. (2012) Flyway protection and the predicament of our migrant birds: a critical look at international conservation policies and the Dutch Wadden Sea. Ocean \& Coastal Management, 68, 157-168.

Borrini-Feyerabend, G., Kothari, A. \& Oviedo, G. (2004) Indigenous and Local Communities and Protected Areas: Towards Equity and Enhanced Conservation. IUCN, Gland, Switzerland and Cambridge, UK.

Brander, L.M., Wagtendonk, A.J., Hussain, S.S., Mcvittie, A., Verburg, P.H., de Groot, R.S. \& van der Ploeg, S. (2012) Ecosystem service values for mangroves in Southeast Asia: a meta-analysis and value transfer application. Ecosystem Services, $1,62-69$.

BUCKTON, S.T. \& SAFFord, R.J. (2004) The avifauna of the Vietnamese Mekong Delta. Bird Conservation International, $14,279-322$.

Chan, Y.C., Tibitts, T.L., Lok, T., Hassell, C.J., Peng, H.B., Ma, Z. et al. (2019) Filling knowledge gaps in a threatened shorebird flyway through satellite tracking. Journal of Applied Ecology, $56,2305-2315$.

Choi, C.Y., Rogers, K.G., Gan, X., Clemens, R.S., Bai, Q.-Q., Lilleyman, A. et al. (2016) Phenology of southward migration of 
shorebirds in the East Asian-Australasian Flyway and inferences about stop-over strategies. Emu, 116, 178-189.

Chou, L.M. (1994) Marine environmental issues of Southeast Asia: state and development. Hydrobiologia, 285, 139-150.

Coleman, J.L., Ascher, J.S., Bickford, D., Buchori, D., Cabanban, A. et al. (2019) Top 100 research questions for biodiversity conservation in Southeast Asia. Biological Conservation, 234, 211-220.

Crossland, A.C., Sinambela, S.A., Sitorus, A.S. \& Sitorus, A.W. (2006) An overview of the status and abundance of migratory waders in Sumatra, Indonesia. Stilt, 50, 90-95.

de GraAf, G.J. \& Xuan, T.T. (1998) Extensive shrimp farming, mangrove clearance and marine fisheries in the southern provinces of Vietnam. Mangroves and Salt Marshes, 2, 159-166.

de Groot, R., Brander, L., van der Ploeg, S., Costanza, R., Bernard, F., Brati, L. \& Hussain, S. (2012) Global estimates of the value of ecosystems and their services in monetary units. Ecosystem Services, 1, 50-61.

Denyer, K., Akoijam, Y., Kenza Ali, M., Khurelbatar, S., Oviedo, G. \& Young, L. (2018) Learning from Experience: How Indigenous Peoples and Local Communities Contribute to Wetland Conservation in Asia and Oceania. Ramsar Convention Secretariat, Gland, Switzerland.

Donato, D.C., Kauffman, J.B., Murdiyarso, D., Kurniato, S., Stidham, M. \& Kanninen, M. (2011) Mangroves among the most carbon-rich forests in the tropics. Nature Geoscience, 4, 293-297.

Duan, H., Xia, S., Jackson, M.V., Zhao, N., Liu, Y., Teng, J. et al. (2020) Identifying new sites of significance to waterbirds conservation and their habitat modification in the Yellow and Bohai Seas in China. Global Ecology and Conservation, 22, e01031.

DURIYAPONG, F. \& NAKHAPAKORN, K. (2011) Coastal vulnerability assessment: a case study of Samut Sakhon coastal zone. Songklanakarin Journal of Science Technology, 33, 469-476.

EaAfp (2018) The Partnership. East Asian-Australasian Flyway Partnership. eaaflyway.net/about-us/the-partnership [accessed 24 July 2018].

ENG, C.T., PAW, J.N. \& GUARIN, F.Y. (1989) The environmental impact of aquaculture and the effects of pollution on coastal aquaculture development in Southeast Asia. Marine Pollution Bulletin, 20, 335-343.

Erftemeijer, P. \& Lewis, R. (1999) Planting mangroves on intertidal mudflats: habitat restoration or habitat conversion? In Proceedings of Regional Seminar for East and Southeast Asian Countries: Ecotone VIII, Ranong \& Phuket, 1999, pp. 156-165. UNESCO, Bangkok, Thailand.

Friess, D.A., Phelps, J., Leong, R.C., Lee, W.K., Wee, A.K.S., Sivasothi, N. \& Webb, E.L. (2012) Mandai mangrove, Singapore: lessons for the conservation of Southeast Asia's mangroves. Raffles Bulletin of Zoology Supplement, 25, 55-65.

Friess, D.A., Yando, E.S., Abuchahla, G.M., Adams, J.B., Cannicci, S., Canty, S.W. et al. (2020) Mangroves give cause for conservation optimism, for now. Current Biology, 30, R153-R154.

Gallo-Cajiao, E., Morrison, T.H., Woodworth, B.K., Lees, A.C., Naves, L.C., YonG, D.L. et al. (2020) Extent and potential impact of hunting on migratory shorebirds in the Asia-Pacific. Biological Conservation, 246, 108582.

Hilton, M.J. \& Manning, S.S. (1995) Conversion of coastal habitats in Singapore: indications of unsustainable development.

Environmental Conservation, 22, 307-322.

Hino, M., Field, C.B. \& MACH, K.J. (2017) Managed retreat as a response to natural hazard risk. Nature Climate Change, 7, 364-37o.

Iqbal, M., Giyanto \& Abdillah, H. (2010) Wintering shorebirds migrate during January 2009 along the east coast of north Sumatra province, Indonesia. Stilt, 58, 18-23.
IUCN (2021) The IUCN Red List of Threatened Species 2021-1. iucnredlist.org [accessed 24 May 2021].

Jackson, M.V., Choi, C.Y., Amano, T., Estrella, S.M., Lei, W., Moores, N. et al. (2020) Navigating coasts of concrete: pervasive use of artificial habitats by shorebirds in the Asia-Pacific. Biological Conservation, 247, 108591.

Jearwattanakanok, A. \& Yong, D.L. (2019) Updates: critical spoon-billed sandpiper habitat in the salt pans of Thailand secured! Spoon-Billed Sandpiper Task Force New Bulletin, 21, 32-33.

JENSEN, A.E. (2018) Internationally Important Waterbird Sites in Manila Bay, Philippines, October 2018. Technical Report. Wetlands International and IUCN National Committee of The Netherlands, Wageningen, The Netherlands.

KIM, E.J. (2018) S. Korea to restore mudflats on western coast by 2023. Yonhap News Agency, 9 July 2018. en.yna.co.kr/view/ AEN20180709001800320 [accessed 24 May 2021].

Kuenzer, C. \& Renaud, F.G. (eds) (2012) Climate and environmental change in river deltas globally: expected impacts, resilience, and adaptation. In The Mekong Delta System, pp. 7-46. Springer, Dordrecht, Germany.

Lai, S., Loke, L.H., Hilton, M.J., Bouma, T.J. \& Todd, P.A. (2015) The effects of urbanisation on coastal habitats and the potential for ecological engineering: a Singapore case study. Ocean \& Coastal Management, 103, 78-85.

Li, D.Z., Yeap, C.A., Lim, K.C., Kumar, K., Lim, A.T., YanG, C. \& Choy, W.M. (2006) Shorebird surveys of the Malaysian coast November 2004-April 2005. Stilt, 49, 7-18.

Lim, H.C. \& Posa, M.R.C. (2014) Distribution and prey of migratory shorebirds on the northern coastline of Singapore. Raffles Bulletin of Zoology, 62, 701-717.

Ma, Z., Melville, D.S., Liu, J., Chen, Y., Yang, H., Ren, W. et al. (2014) Rethinking China's new great wall. Massive seawall construction in coastal wetlands threatens biodiversity.

Science, 346, 912-914.

Mackinnon, J., Verkuil, Y.I. \& Murray, N. (2012) IUCN Situation Analysis on East and SouthEast Asian Intertidal Habitats, with Particular Reference to the Yellow Sea (Including the Bohai Sea). Occasional Paper of the IUCN Species Survival Commission No. 47. IUCN, Gland, Switzerland and Cambridge, UK.

Marcheciello, P., Nguyen, N.M., Gratiot, N., Loisel, H., Anthony, E.J., San Dinh, C. et al. (2019) Erosion of the coastal Mekong delta: assessing natural against man-induced processes. Continental Shelf Research, 181, 72-89.

Mcleod, E., Chmura, G.L., Bouillon, S., Salm, R., Bjork, M., Duarte, C.M. et al. (2011) A blueprint for blue carbon: toward an improved understanding of the role of vegetated coastal habitats in sequestering $\mathrm{CO}_{2}$. Frontiers in Ecology and the Environment, 9, 552-560.

Murray, N.J., Clemens, R.S., Phinn, S.R., Possingham, H.P. \& Fuller, R.A. (2014) Tracking the rapid loss of tidal wetlands in the Yellow Sea. Frontiers in Ecology and Environment, 12, 267-272.

Murray, N.J., Phinn, S.R., Dewitt, M., Ferrari, R., Johnston, R., Lyons, M.B. et al. (2019) The global distribution and trajectory of tidal flats. Nature, 565, 222.

Murata, N., Merriman, J.C., Le, T.T. \& Nguyen, T.K.H. (2016) Case study-Thai Thuy Wetland, Vietnam. In Guide for Rapid Economic Valuation of Wetland Ecosystem Services (eds J.C. Merriman \& N. Murata). BirdLife International Tokyo, Japan.

Myat Moe Aung (2020) Gulf of Mottama Wetland more than triples in size as newest Ramsar site. Myanmar Times, 3 February 2020. mmtimes.com/news/gulf-mottama-wetland-more-triples-sizenewest-ramsar-site.html [accessed 24 May 2021]. 
Nguyen, H.B., CaO, Q.T., Bui, T.T. \& Yong, D.L. (2020) Salt pans and coastal flats on the coast of Binh Thuan-a new site for the spoon-billed sandpiper in Vietnam. Spoon-Billed Sandpiper Task Force New Bulletin, 22, 12-16.

Obst, M., Faurby, S., Bussarawit, S. \& Funch, P. (2012) Molecular phylogeny of extant horseshoe crabs (Xiphosura, Limulidae) indicates Paleogene diversification of Asian species. Molecular Phylogenetics and Evolution, 62, 21-26.

Ooi, J.L.S., Kendrick, G.A., Van Niel, K.P. \& Affendi, Y.A. (2011) Knowledge gaps in tropical Southeast Asian seagrass systems. Estuarine, Coastal and Shelf Science, 92, 118-131.

Pedersen, A. \& Nielsen, S.S. (1998) The status and conservation of threatened and near-threatened species of birds in the Red River Delta, Vietnam. Bird Conservation International, 8, 31-51.

Piersma, T., Lok, T., Chen, Y., Hassell, C.J., Yang, H.-Y., Boyle, A. et al. (2016) Simultaneous declines in summer survival of three shorebird species signals a flyway at risk. Journal of Applied Ecology, 53, 479-49o.

Putra, C.A., Hikmatullah, D., Zöckler, C., Syroechkovskiy, E.E. \& Hughes, B. (2019) Spoon-billed sandpiper: a new species for Indonesia. Wader Study, 126, 60-63.

Putra, C.A., Perwitasari-Farajallah, D. \& Mulyani, Y.A. (2017) Habitat use of migratory shorebirds on the coastline of Deli Serdang Regency, North Sumatra Province. HAYATI Journal of Biosciences, 24, 16-21.

Rahman, S. (2017) Johor's Forest City Face Critical Challenges. Trends in Southeast Asia Series No. 3. Institute of Southeast Asian Studies and Yusof Ishak Institute, Singapore.

Rambaldi, G., Bugna, S. \& Geiger, M. (2001) Review of the protected area system of Vietnam. ASEAN Biodiversity, 1, 43-51.

Ramsar Convention Secretariat (2016) An Introduction to the Ramsar Convention on Wetlands. 7 th edition. Ramsar Convention Secretariat, Gland, Switzerland.

Richards, D.R. \& Friess, D.A. (2016) Rates and drivers of mangrove deforestation in Southeast Asia, 2000-2012. Proceedings of the National Academy of Sciences of the United Stated of America, 113, 344-349.

Round, P.D. (2006) Shorebirds in the Inner Gulf of Thailand. Stilt, 50, 96-102.

Sodhi, N.S., Posa, M.R.C., Lee, T.M., Bickford, D.S, Koh, L.P. \& Brook, B.W. (2010) The state and conservation of Southeast Asian biodiversity. Biodiversity and Conservation, 19, 317-328.

Sripanomyom, S., Round, P.D., Savini, T., Trisurat, Y. \& Gale, G.A. (2011) Traditional salt-pans hold major concentrations of overwintering shorebirds in Southeast Asia. Biological Conservation, 144, 526-537.

Studds, C.E., Kendall, B.E., Murray, N.J., Wilson, H.B., Rogers, D.I., Clemens, R.S. \& Milton, D.A. (2017) Rapid population decline in migratory shorebirds relying on Yellow Sea tidal mudflats as stopover sites. Nature Communications, 8, 14895.

Suratman, M.N. (2008) Carbon sequestration potential of mangroves in Southeast Asia. In Managing Forest Ecosystems: The Challenge of Climate Change (eds F. Bravo, V. LeMay \& R. Jandl), pp. 297-315. Springer, Dordrecht, The Netherlands.
Turrin, C. \& WatTs, B.D. (2016) Sustainable mortality limits for migratory shorebird populations within the East Asian-Australian Flyway. Stilt, 68, 2-17.

Ueta, M., Melville, D.S., Wang, Y., Ozaki, K., Kanai, Y., LEADER, P.J. et al. (2002) Discovery of the breeding sites and migration routes of black-faced spoonbills Platalea minor. Ibis, 144, 340-343.

UNESCO WHC (2019) Migratory Bird Sanctuaries along the Coast of Yellow Sea-Bohai Gulf of China (Phase I). United Nations Educational, Scientific and Cultural Organisation: World Heritage Convention. whc.unesco.org/en/list/1606 [accessed 17 June 2021].

Verheugt, W.J., Skov, H. \& Danielsen, F. (1992) Notes on the birds of the tidal lowlands and floodplains of South Sumatra province, Indonesia. Kukila, 6, 53-84.

Yang, H.Y., Chen, B., Barter, M., Piersma, T., Zhou, C.F., Li, F.S. \& ZHANG, Z.W. (2011) Impacts of tidal land reclamation in Bohai Bay, China: ongoing losses of critical Yellow Sea waterbird staging and wintering sites. Bird Conservation International, 21, 241-259.

Yasue, M. \& Dearden, P. (2009) The importance of supratidal habitats for wintering shorebirds and the potential impacts of shrimp aquaculture. Environmental Management, $43,1108$.

Yeap, C.A., Sebastian, A.C. \& Davison, G.W.H. (2007) Directory of Important Bird Areas in Malaysia - Key Sites for Conservation. Malaysian Nature Society, Kuala Lumpur, Malaysia.

Yong, D.L., Jain, A., Liu, Y., Iqbal, M., Choi, C.Y., Crockford, N.J. et al. (2018) Challenges and opportunities for transboundary conservation of migratory birds in the East Asian-Australasian Flyway. Conservation Biology, 32, 740-743.

Yu, C., Ngoprasert, D., Savini, T., Round, P.D. \& Gale, G.A. (2020) Distribution modelling of the Endangered spotted greenshank (Tringa guttifer) in a key area within its winter range. Global Ecology and Conservation, 22, eoo975.

Zhou, V. (2018) China puts a stop to commercial land reclamation after damning environment reports. South China Morning Post, 2 January 2018. scmp.com/news/china/policies-politics/article/ 2126567/china-puts-stop-commercial-land-reclamation-after [accessed 24 July 2018].

Zöckler, C., Beresford, A.E., Bunting, G., Chowdhury, S.U., Clark, N.A., FU, V.W.K. et al. (2016) The winter distribution of the spoon-billed sandpiper Calidris pygmaeus. Bird Conservation International, 26, 476-489.

Zöckler, C., Zaw Naing, T., Moses, S., Nou Soe, R. \& Htin Hla, T. (2014) The importance of the Myanmar coast for water birds. Stilt, 66, 37-51.

Zöckler, C., Li, D.Z., Chowdhury, S.U., Iqbal, M. \& Yu, C. (2018a) Winter distribution, habitat and feeding behaviour of Nordmann's greenshank Tringa guttifer. Wader Study, 125, 7-14.

Zöckler, C., Aung, P.P., Grindley, M. \& Aung, C. (2018b) Coastal Wetlands in Myanmar - A Directory of Important Sites for Biodiversity. ArcCona Ecological Consultants, Cambridge, UK. 